\title{
Aspergilli and Their Aflatoxins Contamination of Poultry and Animal Feedstuff Samples in Western Region of Saudi Arabia
}

(Aspergili dan Pelumusan Aflatoksin Ayam dan Sampel Makanan Binatang Ternakan di Wilayah Barat Arab Saudi)

\author{
Youssuf A. GHERBAwy, YASSMin M. SHEBANY* \& Helal AlHARTHY
}

\begin{abstract}
Aspergillus and their aflatoxins contaminations were studied in sixty poultry and animal feedstuff samples collected from the western region (Jeddah, Makkah and Taif cities) from Saudi Arabia. Fourteen species of Aspergillus were isolated and identified in the present investigation using Potato Dextrose Agar (PDA) at $27^{\circ} \mathrm{C}$. The identification of isolated Aspergillus was confirmed by using internal transcribed spacer (ITS) region sequencing for representative species (194 species) of the collected Aspergillus sp. were sequenced and the obtained sequence results were deposited in Gene Bank under accession numbers. The sequence results indicated to the full correspondence between the molecular identification of the isolated fungi and the morphological identification. Moisture content was considered indicator for the number of Aspergillus isolated, therefore, Aspergillus and their aflatoxins were isolated in high counts from Jeddah and Taif according to the moisture content. Therefore, A. flavus was the most common species (59.78\%), followed by A. niger (21.59\%). The co-occurrence of Aspergillus species ranged from one species to 6 species per sample. The frequencies of occurrence for most aftoxigenic species isolated from studied samples ranged from 2 to $56 \%$. Aspergillus flavus contaminated the majority of investigated feedstuff samples and the co-occurrence of more than one aflatoxigenic species was reported in many samples.
\end{abstract}

Keywords: Aspergilli; camel; horse; PCR; rabbit; sequencing

ABSTRAK

Aspergillus dan pelumusan aflatoksin telah dikaji dalam enam puluh ekor ayam dan sampel makanan binatang ternakan yang dikumpul dari wilayah Barat (bandar Jeddah, Makkah dan Taif), Arab Saudi. Empat belas spesies Aspergillus telah diasingkan dan dikenal pasti dalam kajian ini menggunakan Agar-agar Kentang Dekstrosa (PDA) pada suhu $27^{\circ} \mathrm{C}$. Pengecaman Aspergillus terasing telah disahkan dengan menggunakan penjujukan rantau dalaman transkripsi penjarak (ITS) untuk wakil spesies (194 spesies) Aspergillus sp. yang terkumpul telah dijujukan dan keputusan jujukan yang diperoleh disimpan di bank gen di bawah nombor penerimaan. Keputusan jujukan menunjukkan kesepadanan penuh antara pengenalan molekul untuk kulat yang terasing dan pengenalan morfologi. Kandungan lembapan dijadikan petunjuk bagi bilangan Aspergillus terasing, begitu juga Aspergillus dan aflatoksinnya telah diasingkan dalam kiraan tinggi dari Jeddah dan Taif mengikut kandungan lembapan. Maka A. flavus ialah spesies paling biasa (59.78\%), diikuti oleh A. niger (21.59\%). Kejadian spesies Aspergillus adalah daripada satu spesies kepada enam spesies setiap sampel. Kekerapan kejadian bagi kebanyakan spesies aflatoksigen yang diasingkan daripada sampel yang dikaji adalah daripada 2 hingga 56\%. Aspergillus flavus mencemarkan majoriti sampel bahan makanan ternakan yang dikaji dan kejadian bersama aflatoksigen lebih daripada satu spesies dilaporkan dalam kebanyakan sampel.

Kata kunci: Arnab; Aspergilli; kuda; PCR; penjujukan; unta

\section{INTRODUCTION}

Livestock production is an important part of national economy and it plays a significant role in providing the high quality food for human beings. Various stresses like low quality feed, naturally occurring toxic contamination in feed stuffs, poor management, diseases, climatic extremes and other constraints are ever present threats that can adversely affect performance and health of animals. Fungi are continuous threat to livestock feeds of economic importance such as compound feeds. They may affect feed either directly by causing mechanical damage throughout feeding, or indirectly by secreting and spreading mycotoxins such as aflatoxins in the case of aflatoxin producing fungi (Iheanacho et al. 2014).

Aflatoxins are secondary metabolites produced by the aflatoxigenic fungi Aspergillus flavus Link and Aspergillus parasiticus Speare (Roehuck \& Maxuitenko 1994). Aflatoxin is associated with both toxicity and carcinogenicity in human and animal populations (Eaton \& Gallagher 1994; Wogan 1992). Aflatoxicosis is poisoning resulting from ingestion of moderate to high levels of aflatoxins in contaminated food or feed. Toxicological studies demonstrate that ducklings, hamsters, rats, trout, rabbits, and a number of other vertebrates are all susceptible 
to aflatoxin poisoning. Acute aflatoxicosis results in rapid progressive jaundice, edema of the limbs, pain, vomiting, necrosis, cirrhosis, or in severe cases, acute liver failure and death (CDC 2004; Fung \& Clark 2004; Lewis et al. 2005; Yu et al. 2007).

In Saudi Arabia, so far, little published information is available about fungal mycobiota in agricultural products particularly those used as ingredients in poultry and animal feeds. Only sporadic reports covering short periods and smaller regions described the presence of some toxigenic fungi or mycotoxins in agricultural products (Abdel-Hafez 1984; Gashgari et al. 2010; Kassim 1987; Sejiny et al. 1984; Yassin et al. 2010) and animal feed stuffs (Al-Julaifi \& Al-Falih 2001; Bokhari 2010). In the absence of sufficient basic data, recommendations for control and prevention of contamination by toxigenic fungi in agricultural based feed ingredients cannot be made. This may lead to continuous exposure of livestock and poultry birds to mycotoxins resulting in losses to livestock and poultry industry in the form of increased mortality and decreased productions. The food products from these animals like milk, eggs or meat may also carry mycotoxin residues into human food chain.

Due to the humid nature for two of the selected area (Jeddah and Makkah) in comparison with moderate area like Taif cities hence, this study aims at isolating and identifying Aspergillus species and their aflatoxins that can contaminate animal and poultry feedstuffs in the western region of Saudi Arabia (Jeddah, Makkah and Taif cities).

\section{MATERIALS AND METHODS}

\section{SAMPLE COLLECTING AND HANDLING STRATEGY}

Sixty samples of loosely mixed animal (camel, cattle, horses, poultry and rabbit) forage ready for feeding were collected from feed factories, storehouse and fodder markets from different vendors at Jeddah, Makkah and Taif regions. Samples (each about $1 \mathrm{~kg}$ ) were collected from the investigated regions in Saudi Arabia. Primary samples were homogenized, milled, and quartered to get $500 \mathrm{~g}$ laboratory samples. Proximate microbiological quality and identification of natural mycobiota were done the day after collection. Another portion of samples was stored at $-20^{\circ} \mathrm{C}$ up to one week for analysis of initial mycotoxin levels (Pereyra et al. 2010).

\section{MOISTURE CONTENT}

The moisture content of the collected samples was determined by heating a sample in a drying oven at a temperature above the boiling point of water (100 to $105^{\circ} \mathrm{C}$ ) to constant weight (the loss in weight being calculated as percent moisture) (AOAC 2005- Official Method 925.04 and 934.01).

\section{ENUMERATION, ISOLATION AND IDENTIFICATION OF FUNGI}

Quantitative enumeration of fungal colony-forming units (CFU) was done on PDA media using the surface-spread method (Bokhari 2010; Kacaniova 2003). Twenty grams of ground sample were soaked in $100 \mathrm{~mL}$ sterile saline water $(9 \mathrm{~g} / \mathrm{L})$ containing $0.02 \%$ Tween 80 and shacked $30 \mathrm{~min}$. One hundred $\mu \mathrm{L}$ aliquots were inoculated onto three plates of PDA media. Plates were then incubated at $27^{\circ} \mathrm{C}$ for 7 days. All colonies were transferred for subculturing to plates of Malt Extract Agar (MEA). Taxonomic identification of the different genera and species was made according to macroscopic and microscopic criteria with appropriate keys (Klich 2002; Nelson et al. 1983; Pitt \& Hocking 1998; Samson et al. 2000).

\section{MOLECULAR IDENTIFICATION OF FUNGAL ISOLATES}

\section{DNA ISOLATION}

Two $\mathrm{mL}$ of potato dextrose broth (PDB) were poured into tubes and vortexed to disperse the spores, and the spores-PDB mix were poured into flasks containing 100 $\mathrm{mL}$ of PDB. Flasks were incubated at room temperature without shaking for 2 to 3 days. The mycelium was harvested by filtration, frozen at $-80^{\circ} \mathrm{C}$ during $30 \mathrm{~min}$, lyophilized and stored at $-80^{\circ} \mathrm{C}$. The mycelium was ground in liquid nitrogen in a sterile mortar to obtain a mycelium powder. The DNA was extracted from $20 \mathrm{mg}$ of mycelium powder using DNeasy plant mini kit. The DNA quantity and quality were checked by electrophoresis on a $0.8 \%$ agarose gel, revealed with ethidium bromide and visualized by UV trans-illumination (Gherbawy \& Gashgari 2013).

\section{ITS REGION SEQUENCING}

The internal transcribed spacer (ITS) region of the ribosomal DNA (rDNA) was amplified by PCR with the primers ITS1-F (CTTGGTCATTTAGAGGAAGTAA) and ITS4 (TCCTCCGCTTATTGATATGC) (Gardes \& Bruns 1993; White et al. 1990). PCR amplifications were done in a final volume of $50 \mu \mathrm{L}$ by mixing $2 \mu \mathrm{L}$ of DNA with $0.5 \mu \mathrm{M}$ of each primer, $150 \mu \mathrm{M}$ of dNTP, $1 \mathrm{U}$ of Taq DNA polymerase (Promega) and PCR reaction buffer. Amplification conducted in a thermal cycler with an initial denaturation of $3 \mathrm{~min}$ at $94^{\circ} \mathrm{C}$, followed by 35 cycles of $1 \mathrm{~min}$ at $94^{\circ} \mathrm{C}, 1 \mathrm{~min}$ at $50^{\circ} \mathrm{C}, 1 \mathrm{~min}$ at $72^{\circ} \mathrm{C}$, and a final extension of $10 \mathrm{~min}$ at $72^{\circ} \mathrm{C}$. Aliquots of PCR products were checked by electrophoresis on a $1 \%$ agarose gel revealed with ethidium bromide and visualized by UV trans-illumination. The PCR products were purified by ExoSAP-IT (USB Corporation, under license from GE Healthcare) based one manufacturer's instructions. The purified products were sequenced using an automated DNA sequencer (ABI PRISM 3700) using the BigDye Deoxy Terminator cycle-sequencing kit (Applied Biosystems) following manufacturer's instructions. Sequences were submitted to GenBank on the NCBI website (http://www. ncbi.nlm.nih.gov). Sequences obtained in this study were compared with the GenBank database using the BLAST 
software on the NCBI website (http://www.ncbi.nlm.nih. gov/BLAST/).

\section{DETECTION OF NATURAL OCCURRENCE OF TOTAL AFLATOXINS (AFs) IN FEEDSTUFF SAMPLES}

Sixty samples were analyzed for total aflatoxins (AFs) using a slightly modified immunoaffinity method based on Association of Official Analytic Chemists (AOAC) method (Truckess et al. 1991). As previously described by Lewis et al. (2005), the whole sample was ground and a $100 \mathrm{~g}$ subsample was removed for analysis. Methanol: water $(80: 20)$ solvent $(100 \mathrm{~mL})$ and $5 \mathrm{~g} \mathrm{NaCl}$ were added to each sample and the mixture was blended at high speed for $3 \mathrm{~min}$. The mixture was then filtered through a fluted filter paper (Whatman 2V, Whatmanplc, Middlesex, UK), and the filtrate was diluted (1:4) with water and refiltered through a glass-fiber filter paper. Two milliliters of the glass-fiber filtrate were placed on AflaTest ${ }^{\circledR}$ WB SR Column (VICAM, Watertown, MA, USA) and allowed to elute at 1-2 drops/s. The columns were washed two times with $5 \mathrm{~mL}$ water, and aflatoxin was eluted from the column with $1 \mathrm{~mL}$ high performance liquid chromatography (HPLC)-grade methanol. A bromine developer $(1 \mathrm{~mL})$ was added to the methanol extract, and the total aflatoxin concentration was read in a recalibrated VICAMSeries-4 fluorometer set at $360 \mathrm{~nm}$ excitation and $450 \mathrm{~nm}$ emissions.

\section{RESULTS AND DISCUSSION}

Sixty samples of poultry and animal feedstuff samples were collected from western region of Saudi Arabia (Jeddah, Makkah and Taif). Twenty samples from each city were used for isolation and identification of fungi and aflatoxin contaminations. Moisture content was considered indicator for the number of fungi isolated. The highest moisture content of poultry and animal feedstuff samples was observed from Jeddah city $(8.4 \%)$, while the lowest sample of moisture content was observed from Makkah city (3.2\%). The highest moisture content of poultry and animal feedstuff samples was recorded in poultry feedstuff samples, but the lowest moisture content was appeared in cattle feedstuff samples (Table 1). Moisture content and ambient temperature are key factors affecting fungal colonization and mycotoxin production in grains and compound feeds (Okoli 2005). Contaminating fungi grow best when the moisture

TABLE 1. The moisture contents and total aflatoxins (PPB) contaminated different poultry and animal feedstuff samples collected from different cities in the western region of Saudi Arabia

\begin{tabular}{|c|c|c|c|c|c|c|c|c|c|}
\hline No. & Sample Type & Location & $\begin{array}{l}\text { Total } \\
\text { AFs* }\end{array}$ & $\begin{array}{c}\text { Moisture } \\
\text { Content }\end{array}$ & No. & $\begin{array}{l}\text { Sample } \\
\text { Type }\end{array}$ & Location & $\begin{array}{l}\text { Total } \\
\text { AFs* }\end{array}$ & $\begin{array}{l}\text { Moisture } \\
\text { Content }\end{array}$ \\
\hline 1 & Camel \& cattle & Taif & 3.7 & 6.4 & 31 & Cattle & Makkah & 4.76 & 5.8 \\
\hline 2 & Camel \& cattle & Taif & 13 & 7.0 & 32 & Poultry & Makkah & 1.4 & 6.5 \\
\hline 3 & Camel \& cattle & Taif & 12 & 6.5 & 33 & Cattle & Makkah & 4.50 & 6.5 \\
\hline 4 & Camel \& cattle & Taif & 5.6 & 6.3 & 34 & Rabbit & Makkah & 7.1 & 6.6 \\
\hline 5 & Cattle & Taif & 7.6 & 6.6 & 35 & Poultry & Makkah & 0.75 & 5.0 \\
\hline 6 & Cattle & Taif & 8 & 6.6 & 36 & Poultry & Makkah & 3.11 & 7.3 \\
\hline 7 & Cattle & Taif & 6.7 & 6.8 & 37 & Poultry & Makkah & 2.9 & 7.1 \\
\hline 8 & Poultry & Taif & 33 & 6.4 & 38 & Camel \& cattle & Makkah & 6.0 & 7.7 \\
\hline 9 & Poultry & Taif & 3.1 & 6.5 & 39 & Poultry & Makkah & 60 & 6.4 \\
\hline 10 & Camel \& cattle & Taif & 12 & 5.3 & 40 & Poultry & Makkah & 7.6 & 6.3 \\
\hline 11 & Cattle & Taif & 4.3 & 7.1 & 41 & Poultry & Jeddah & 4.8 & 6.2 \\
\hline 12 & Poultry & Taif & 1.9 & 5.5 & 42 & Poultry & Jeddah & 14 & 7.3 \\
\hline 13 & Poultry & Taif & 9.3 & 5.2 & 43 & Poultry & Jeddah & 7.4 & 6.3 \\
\hline 14 & Poultry & Taif & 3.1 & 6.4 & 44 & Poultry & Jeddah & 15 & 8.1 \\
\hline 15 & Poultry & Taif & 2.2 & 5.7 & 45 & Poultry & Jeddah & 9.4 & 8.4 \\
\hline 16 & Poultry & Taif & 22 & 4.1 & 46 & Poultry & Jeddah & 1.6 & 7.0 \\
\hline 17 & Poultry & Taif & 1.8 & 6.7 & 47 & Camel \& cattle & Jeddah & 1.3 & 8.3 \\
\hline 18 & Poultry & Taif & 12 & 6.2 & 48 & Camel \& cattle & Jeddah & 6.7 & 6.7 \\
\hline 19 & Rabbit & Taif & 6.5 & 6.6 & 49 & Camel \& cattle & Jeddah & 1.5 & 7.3 \\
\hline 20 & Poultry & Taif & 2.8 & 6.4 & 50 & Poultry & Jeddah & 7.9 & 7.1 \\
\hline 21 & Poultry & Makkah & 1.3 & 6.3 & 51 & Poultry & Jeddah & 1.8 & 6.5 \\
\hline 22 & Cattle & Makkah & 1.0 & 6.2 & 52 & Poultry & Jeddah & 0.90 & 7.8 \\
\hline 23 & Cattle & Makkah & 5.1 & 6.9 & 53 & Camel \& cattle & Jeddah & 7.3 & 7.0 \\
\hline 24 & Poultry & Makkah & 2.2 & 7.2 & 54 & Camel \& cattle & Jeddah & 8.5 & 7.2 \\
\hline 25 & Camel \& cattle & Makkah & 8.0 & 5.5 & 55 & Camel \& cattle & Jeddah & 3.3 & 8.1 \\
\hline 26 & Cattle & Makkah & 2.7 & 3.2 & 56 & Camel \& cattle & Jeddah & 3.8 & 6.2 \\
\hline 27 & Camel \& cattle & Makkah & 5.4 & 6.7 & 57 & Horses & Jeddah & 0.64 & 6.1 \\
\hline 28 & Poultry & Makkah & 6.0 & 7.0 & 58 & Camel \& cattle & Jeddah & 4.0 & 6.0 \\
\hline 29 & Poultry & Makkah & 2.2 & 6.3 & 59 & Cattle & Jeddah & 4.4 & 6.8 \\
\hline 30 & Cattle & Makkah & 0.61 & 5.4 & 60 & Cattle & Jeddah & 3.0 & 7.2 \\
\hline
\end{tabular}


contents of the feed are 14.5 to $20 \%$ and in equilibrium with a relative humidity of 70 to $90 \%$ (Chow 1980). In Serbia, Krnjaja et al. (2014) recorded that, the moisture content of the poultry feed samples ranged from 8.04 to $12.67 \%$ with an average of $10.92 \%$.

\section{ASPERGILLUS OF MIXED POULTRY AND ANIMAL FEEDSTUFF SAMPLES}

The dilution plate method was used for the estimation of fungi from poultry and animal feedstuff samples on Potato Dextrose Agar (PDA) at $27^{\circ} \mathrm{C}$. The collected Aspergillus sp. were identified with microscopic examination with appropriate keys (Christensen \& Raper 1978; Lawerence 1989; Moubasher 1993; Raper \& Fennell 1965; Samson 1979). Also, the identification of Aspergillus was confirmed by using PCR-based methods. Internal transcribed spacer regions (ITS) of rRNA for representative species (194 species) of the collected Aspergillus sp. were sequenced and the obtained sequence results were deposited in Gene Bank under accession numbers as shown in Table 2. The sequence results indicated to the full correspondence between the molecular identification of the isolated fungi and the morphological identification.

Fourteen species belonging to Aspergillus sp. were isolated and identified from 60 samples of mixed feedstuff samples on PDA medium at $27^{\circ} \mathrm{C}$ (Table 2). The average total counts of Aspergillus sp. on PDA medium in poultry and feedstuff widely ranged from 9.9 to 2201.1 colonies/g dry feedstuff. From Tamilnadu, Sivakumar et al. (2014) reported that nearly $83 \%$ of animal feed samples were infected with Aspergillus species and the poultry feed seems to be more predominant animal feed that are infected with such genus. The frequencies of occurrence of Aspergillus from poultry feed stuff samples from Brazil was 33.33\% (Oliveira et al. 2006).
A. flavus was the most dominant species in this investigation comprising $59.78 \%$ of total aspergilla and recovered from 56 samples on PDA medium. A. niger ranked second in the count and in the number of cases of isolation, which was recovered from 47 samples constituting $21.59 \%$ of total aspergilla on PDA medium. $A$. amstelodami occupied the third place, which was recovered from 14 samples comprising $3.58 \%$ of total aspergilla on PDA medium (Table 2).

A.chevalieri, A.ochareceous, A.oryzae, A.parasiticus, A. sydowi and A.terreus were isolated with low occurrence and counts which comprising collectively $11.29 \%$ of total aspergilla and were recovered from 12 samples. The remaining species were recovered with rare occurrence, therefore, these species were isolated from 5 samples only and constituting collectively $3.76 \%$ of total aspergilla (Table 2).

Mostafa and Amer (2013) isolated Aspergillus flavus, A. fumigatus, A. niger and A. ochraceous from eleven animal feed samples were collected from El-Gharbia Government, Egypt. These samples included wheat, chopped rice wheat flour, wheat bran maize flour rice bran, and poultry feed. Recently, Ezekiel et al. (2014) isolates a total of 1006 Aspergillus section Flavi isolates from 51 of the $58(87.9 \%)$ poultry feed samples from Nigeria.

\section{CO-OCCURRENCE OF ASPERGILLI IN FEEDSTUFF SAMPLES}

Table (3) shows the co-occurrence of Aspergillus species in feed samples on PDA medium from three cities (Jeddah, Makkah and Taif cities) in Saudi Arabia. So the number of Aspergillus species per samples ranged from 0-6 species on PDA medium. On PDA medium, Aspergillus species isolated from all samples, the highest number of Aspergillus species (6 species per sample) was recovered from one sample in Taif city, but the lowest number of Aspergillus species

TABLE 2. Average total counts (ATC, calculated per g dry feedstuff sample), abundance (out of total counts) and occurrence (out of 60 samples) of fungal genera and species isolated from 60 samples of mixed feedstuff samples on PDA medium at $27^{\circ} \mathrm{C}$ and their accession numbers

\begin{tabular}{ccccc}
\hline $\begin{array}{c}\text { Fungal genera \& } \\
\text { species }\end{array}$ & ATC & Abundance & $\begin{array}{c}\text { Occurrence } \\
(\%)\end{array}$ & $\begin{array}{c}\text { Accession } \\
\text { numbers }\end{array}$ \\
\hline Aspergillus & 3682.8 & 100 & $60(100)$ & - \\
A. amstelodami & 132 & 3.58 & $14(3.3)$ & LN482415 \\
A. caespitosus & 9.9 & 0.27 & $2(3.3)$ & LN482450 \\
A. chevalieri & 75.9 & 2.06 & $11(8.3)$ & LN482478 \\
A. cristatus & 9.9 & 0.27 & $2(3.3)$ & LN482410 \\
A. flavus & 2201.1 & 59.78 & $56(93.3)$ & LN482439 \\
A. fumigatus & 16.5 & 0.45 & $3(5.0)$ & LN482424 \\
A. niger & 795.3 & 21.59 & $47(78.3)$ & LN482469 \\
A. nomius & 42.9 & 1.16 & $5(8.3)$ & LN482574 \\
A. ochareceous & 42.9 & 1.16 & $7(11.7)$ & LN482590 \\
A. oryzae & 118.8 & 3.23 & $11(18.3)$ & LN482484 \\
A. parasiticus & 49.5 & 1.34 & $9(15.0)$ & LN482422 \\
A. rubrum & 23.1 & 0.63 & $3(5.0)$ & LN482567 \\
A. sydowii & 39.6 & 1.08 & $7(11.7)$ & LN482467 \\
A. terreus & 89.1 & 2.42 & $12(20.0)$ & LN482426 \\
\hline
\end{tabular}


(single species per sample) was recovered from 6 samples collected from the three cities (Table 3).

From the literature, several authors reported that Aspergillus flavus A. nomius and A. parasiticus were able to be aflatoxigenic (Murphy et al. 2006; Olsen et al. 2008). Therefore, the co-occurrence of those species was given more attention. The occurrence of aflatoxigenic species belonging to Aspergillus isolated on PDA medium were shown in table (4), where A. flavus isolated from 56 samples, 20 samples from Jeddah city, and 18 samples from each Taif and Makkah city, but $A$. nomius was recovered from 5 samples, which recovered from 2 samples from each Taif and Makkah city, but one sample from Jeddah city. $A$. parasiticus isolated from 9 samples, 3 samples from each city. Gherbawy et al. (2015) studied the co-occurrence of Aspergillus species in chili samples, where $30 \%$ of the samples were not contaminated with Aspergillus species, but $70 \%$ of the samples contaminated with Aspergillus species. The percentage of $13.33 \%$ from the samples is contaminated by one species, $18.33 \%$ is contaminated by two species, and also $18.33 \%$ of the samples contaminated by three species. The percentage of samples contaminated by 4 species was $16.66 \%$, while $3.33 \%$ of the samples contaminated by five species.

\section{NATURAL OCCURRENCE OF TOTAL AFLATOXINS IN FEEDSTUFF SAMPLES}

All tested samples were contaminated with AFs (Table 1). The total aflatoxins were recovered from 60 samples of poultry and animal feeds from three cities in Saudi Arabia (Jeddah, Makkah and Taif). The level of AFs detected in collected samples ranged from 0.61 to $60 \mathrm{ppb}(\mu \mathrm{g} / \mathrm{kg})$. The range of AFs levels in poultry, cattle and camel and cattle samples were 0.90-60, 1.0-7.6 and 1.3-13 ppb, respectively. Also, the obtained results showed that, sample No. 39 of poultry feed, which collected from Makkah had grand total aflatoxins $(60 \mathrm{ppb})$, while sample No. 30 (cattle feeds) collected from Makkah appeared lowest level of total aflatoxins (0.61 ppb). Fifty samples $(83.3 \%)$ and 29 samples (48.3\%) contaminated with AFs less than 10 and 5 ppb, respectively. On the other hand, 10 samples $(16.7 \%)$ contained AFs higher than $10 \mathrm{ppb}$ (Table 8). An earlier study on the levels of aflatoxins in poultry feed from Kuwait's market (Natour et al. 1982), showed contamination in $63.9 \%$ of the samples, with levels of aflatoxin B1 varying from 6 to 201 and of aflatoxin B2 from 8 to $335 \mathrm{ppb}$. Bokhari (2010) reported that contamination of compound feed with aflatoxin and ochratoxin A was ranged from 1 to $6.4 \mathrm{ppb}$ and 1 to $4.7 \mathrm{ppb}$, respectively. Becha and Devi (2013) reported that, the AFs ranges in cattle, rabbit and poultry feed samples were 2-100, 1-88 and 2-400 $\mathrm{ppb}$, respectively. Also, they claimed that, levels of total aflatoxin varied from 1 to $680 \mathrm{ppb}$ among different feed ingredients, the mean levels were found to be very high in maize (122 $\pm 53.36 \mathrm{ppb})$ and ground nut cake (139.75 \pm $31.1 \mathrm{ppb}$ ). Forty-four samples out of 49 samples of poultry feeds collected from different localities in Argentina were contaminated with aflatoxins (median $2.685 \mathrm{ppb}$ ) as recorded by Gerco et al. (2014).

Finally, Aspergillus flavus contaminated the majority of investigated feedstuff samples and the co-occurrence of more than one aflatoxigenic species was reported in many samples. Also, none of feedstuff samples was free from AFs. Some of samples showed levels of AFs above acceptable limits, despite the extent of contamination, the risk is minimal. Finding a practical strategy to reduce the risk of aflatoxin contamination of food and feed is vital.

TABLE 3. Co-occurrence of Aspergillus species in feed samples isolated on PDA medium. Values in brackets are percentages of the total samples analyzed

\begin{tabular}{lcccccc}
\hline Samples location & \multicolumn{7}{c}{ No. species per sample (\%) } \\
& \multicolumn{1}{c}{} & \multicolumn{1}{c}{} & \\
\cline { 2 - 7 } & 1 & 2 & 3 & 4 & 5 & 6 \\
\hline Taif & $4(20)$ & $3(15)$ & $1(5)$ & $7(35)$ & $4(20)$ & $1(5)$ \\
Makkah & $1(5)$ & $4(20)$ & $6(30)$ & $4(20)$ & $4(20)$ & $0(0)$ \\
Jeddah & $1(5)$ & $6(30)$ & $8(40)$ & $4(20)$ & $1(5)$ & $0(0)$ \\
Total & 6 & 13 & 15 & 15 & 9 & 1 \\
& $(10)$ & $(21.7)$ & $(25)$ & $(25)$ & $(15)$ & $(1.7)$ \\
\hline
\end{tabular}

TABLE 4. The frequencies of occurrence of aflatoxigenic species that belonging to Aspergillus species isolates on PDA medium in this study

\begin{tabular}{lcccc}
\hline \multirow{2}{*}{ Samples location } & \multicolumn{3}{c}{ Aspergillus species } & \multirow{2}{*}{ Total } \\
\cline { 2 - 4 } & A. flavus & A. nomius & A.parasiticus & \\
\hline Taif & 18 & 2 & 3 & 23 \\
Makkah & 18 & 2 & 3 & 23 \\
Jeddah & 20 & 1 & 3 & 24 \\
Total & 56 & 5 & 9 & \\
\hline
\end{tabular}




\section{ACKNOWLEDGEMENTS}

This work was supported partially by a graduate student grant (35-40) from King Abdul Aziz City for Science and Technology (KACST) Saudi Arabia.

\section{REFERENCES}

Abdel-Hafez, S.I. 1984. Composition of fungal flora of four cereal grains in Saudi Arabia. Mycopathol. 85: 53-57.

Al-Julaifi, M.Z. \& Al-Falih, A.M. 2001. Detection of trichothecenes in animal feeds and foodstuffs during the years 1997 to 2000 in Saudi Arabia. J. Food Prot. 64: 1603-1606.

Association of Official Analytical Chemists International (AOAC). 2005. Official Methods of Analysis of AOAC International, 18th ed. Gaithersburg, Maryland: AOAC International.

Becha, B.B. \& Devi, S.S. 2013. Aflatoxin levels in feeds and feed ingredients of livestock and poultry in Kerala. J. Vet. Animal Sci. 44: 76-78.

Bokhari, F.M. 2010. Implications of fungal infections and mycotoxins in camel diseases in Saudi Arabia. Saudi. J. Biol. Sci. 17: 73-81.

Center for Disease Control and Prevention (CDC). 2004. Outbreak of aflatoxin poisoning-eastern and central province. Kenya, January-July, 2004. MMWR Morb. Mortal Weekly Report 53: 790-792.

Chow, K.W. 1980. Fish Feed Technology. UNFAO, Rome, Italy. pp. 216-224.

Christensen, C.M. \& Raper, K.P. 1978. Synoptic key to Aspergillus nidulans group species and related Emericella species. Trans. Br. Mycol. Soc. 71: 177-191.

Eaton, D.L. \& Gallagher, E.P. 1994. Mechanisms of aflatoxin carcinogenesis. Ann. Rev. Pharm. Tox. 34: 135-172.

Ezekiel, C.N., Atehnkeng, J., Odebode, A.C. \& Bandyopadhyay, R. 2014. Distribution of aflatoxigenic Aspergillus section Flavi in commercial poultry feed in Nigeria. Inter. J. Food Microb. 189: 18-25.

Fung, F. \& Clark, R.F. 2004. Health effects of mycotoxins: A toxicological overview. J. Tox. Clin. Toxicol. 42: 217-234.

Gardes, M. \& Bruns, T.D. 1993. ITS primers with enhanced specificity for Basidiomycetes-Application to the identification of mycorrhizae and rusts. Molecul. Ecol. 2: 113-118.

Gashgari, R.M., Shebany, Y.M. \& Gherbawy, Y.A. 2010. Molecular characterization of mycobiota and aflatoxins contamination of retail wheat flours from Jeddah markets. Foodborne Path. Dis. 7: 1047-1045.

Gherbawy, Y.A. \& Gashgari, R.M. 2013. Mycobiota associated with superficial blemishes of potato tubers. Food Biotechnol. 27(2): 137-151.

Gherbawy, Y.A., Shebany, Y.M., Hussein, M.A. \& Maghraby, T.A. 2015. Molecular detection of mycobiota and aflatoxins contamination of chili. Arch. Biol. Sci. 67(1): 223-234.

Greco, M.V., Franchi, M.L., Golba, S.L.R., Pardo, A.G. \& Pose, G.M. 2014. Mycotoxins and mycotoxigenic fungi in poultry feed for food-producing animals. The Scientific World Journal 2014: 968215.

Iheanacho, H.E., Njobeh, P.B., Dutton, F.M., Steenkamp, P.A., Steenkamp, L., Mthombeni, J.Q., Daru, B.H. \& Makun, A.H. 2014. Morphological and molecular identification of filamentous Aspergillus flavus and Aspergillus parasiticus isolated from compound feeds in South Africa. Food Microbiol. 44: 180-184.
Kacàniovà, M. 2003. Feeding soybean colonization by microscopic fungi. Trakya Univ. J. Sci. 4: 165-168.

Kassim, M.Y. 1987. A study on seed-borne fungi of barley in Saudi Arabia. Food and Agriculture Organization of the United Nation 47: 115-120.

Klich, M.A. 2002. Identification of common Aspergillus species. Utrecht, the Netherlands: CBS.

Krnjaja, V., Pavlovski, Z., Lukić, M., Škrbić, Z., Stojanović, L., Bijelić, Z. \& Mandić, V. 2014. Fungal contamination and natural occurrence of T-2 toxin in poultry feeds. Biotech. Animal Hus. 30: 321-328.

Lawrence, Z. 1989. Aspergillus and Penicillium definition of the genera. Ferry Lane, Kew, Surrey: C.A.B. International Mycol. Inst.

Lewis, L., Onsongo, M. \& Njapau, H. 2005. Aflatoxicosis investigation group, aflatoxin contamination of commercial maize products during an outbreak of acute aflatoxicosis in Eastern and Central Kenya. Environmental Health Perspectives 113: 1763-1767.

Mostafa, A.A. \& Amer, S.M. 2013. Molecular characterization of toxigenic Aspergillus flavus strains isolates from animal feed stuff in Egypt. Life Sci. J. 10: 1102-1109.

Moubasher, A.H. 1993. Soil Fungi in Qater and Other Arab Countries. The Centre for Scientific and Applied Research: University of Qatar.

Murphy, P.A., Hendrich, S., Landgren, C. \& Bryant, C.M. 2006. Food mycotoxins: An update. J. Food Sci. 71: 51-65.

Natour, R.M., Al-Awadi, A., Illian, M. \& Salman, A.J. 1982. Aflatoxin and aflatoxigenic fungi in poultry feed in Kuwait AG-28. Dirasat. Med. Biol. Sci. 12: 43-52.

Nelson, P.E., Toussoun, T.A. \& Marasas, W.F.O. 1983. Fusarium Species: An Illustrated Manual for Identification. University Park and London, UK: The Pennsylvania State University Press.

Okoli, I.C. 2005. Mycotoxin contamination of feedstuff and mycotoxicoses are neglected livestock production research topics in Nigeria. In Reducing Impact of Mycotoxins in Tropical. Agriculture with emphasis on Health and Trade in Africa. p. 65.

Oliveira, G.R., Ribeiro, J.M., Fraga, M.E., Cavaglieri, L.R., Direito, G.M., Keller, K.M., Dalcero, A.M. \& Rosa, C.A. 2006. Mycobiota in poultry feeds and natural occurrence of aflatoxins, fumonisins and zearalenone in the Rio de Janeiro State, Brazil. Mycopathol. 162: 355-362.

Olsen, M., Johnsson, P., Möller, T., Paladino, R. \& Lindblad, M. 2008. Aspergillus nomius, an important aflatoxin producer in Brazil nuts? World Mycot. J. 1: 123-126.

Pereyra, C.M., Cavaglieri, L.R., Chiacchiera, S.M. \& Dalcero, A.M. 2010. Fungi and mycotoxins in feed intended for sows at different reproductive stages in Argentina. Vet. Med. Int. 18: 31-36.

Pitt, J.I. \& Hocking, A.D. 1998. Fungi and Food Spoilage. 2nd ed. London: Chapman \& Hall.

Raper, K.B. \& Fennell, D.J. 1965. The Genus Aspergillus. Baltimore: Williams and Wilkins. p. 686.

Roehuck, B.D. \& Maxuitenko, Y.Y. 1994. Biochemical mechanisms and biological implication of the toxicity of aflatoxins as related to aflatoxin carcinogenesis. In The Toxicology of Aflatoxins: Human Health, Veternary and Agricultural Significance, edited by Eaton, D.L. \& Groopman, J.D. San Diego: Academic Press. pp. 27-41.

Samson, R.A. 1979. A complication of the aspergilli described since 1965. Studies in Mycologia 18: 1-39. 
Samson, R.A., Hockstra, E.S., Frisvad, J.C. \& Filtenborg, O. 2000. Introduction to Food and Airborne Fungi. Wageningen, the Netherlands: Centaalbureau VoorschimmelcultursUtrecht Ponson and Looyen, Wageningen Press.

Sejiny, M.J., Tawfik, K.A. \& El-Shaieb, M.K. 1984. Studies on mycoflora of cereal grains in the Southern West region of Saudi Arabia, I. Fungi associated with some cereal grains at post harvest and during storage. Ann. Agric. Sci. Moshtohor. 22: $177-281$

Sivakumar, V.K., Singaravelu, G. \& Sivamani, P. 2014. Isolation, characterization and growth optimization of toxicogenic molds from different animal feeds in Tamil Nadu. Inter. J. Current Microbiol. App. Sci. 3: 430-445.

Truckess, M.W., Stack, M.E., Nesheim, S., Page, S.W., Albert, R.H. \& Hansen, T.J. 1991. Immunoaffinity column coupled with solution fluorometry or liquid chromatography postcolumn derivatization for determination of aflatoxins in corn, peanuts, peanut butter: Collaborative study. J. Ass. Official Anal. Chem. 74: 81-88.

White, T.J., Bruns, T., Lee, S. \& Taylor, J. 1990. Amplification and direct sequencing of fungal ribosomal RNA genes for phylogenetics. In PCR Protocols. A Guide to Methods and Applications, edited by Innis, M.A., Gelfand, D.H., Sninsky, J.J. \& White, T.J. San Diego: Academic Press. pp. 315-322.

Wogan, G.N. 1992. Aflatoxins as risk factors for hepatocellular carcinoma in humans. Cancer Res. 52: 2114-2118.

Yassin, M.A., El-Samawaty, A., Bahkali, A., Moslem, M., AbdElsalam, K.A. \& Hyde, K.D. 2010. Mycotoxin-producing fungi occurring in sorghum grains from Saudi Arabia. Fungal Diversity 44: 45-52.
Yu, J., Payne, G.A., Campbell, B.C., Guo, B., Cleveland, T.E., Roberts, J.F., Keller, N.P., Bennett, J.W. \& Nierman, W.C. 2007. Mycotoxin production and prevention of aflatoxin contamination in food and feed. In The Aspergilla: Genomics Medical Aspects, Biotechnology, and Research Methods, edited by William, C.N., Thomas, E.C., Payne, G.A., Keller, N.P., Campbell, B.C., Bennett, J.W., Guo, B., Yu, J. \& Robens, J.F. Boca Raton: CRC Press. pp. 457-472.

Youssuf A. Gherbawy, Yassmin M. Shebany* \& Helal Alharthy Biology Department, Faculty of Science

Taif University, Taif 888

Saudi Arabia

Youssuf A. Gherbawy \& Yassmin M. Shebany*

Botany Department, Faculty of Science

South Valley University, Qena

Egypt

*Corresponding author; email: yoyomsh@yahoo.com

Received: 12 August 2017

Accepted: 4 June 2018 